\title{
MEDICINES WASTE POLICIES AND THE POPULATION KNOWLEDGE IN BRAZIL
}

\author{
THAIS MOURA GASCON BELARDOa, FERNANDO L. A. FONSECA, \\ FERNANDES ANDRADEa, MIRIAM MARQUETE REIS ${ }^{a}$, ODAIR RAMOS ${ }^{a}$, JOICE ANAIZE TONON DO AMARAL ${ }^{c}$, LIGIA \\ AJAIME AZZALIS ${ }^{b}$, VIRGINIA JUNQUEIRA ${ }^{b}$, RENATA SALATINIc, RODRIGO DAMINELLO RAIMUNDOa,d, TATIANA \\ DIAS D. E. CARVALHO ${ }^{\mathrm{a}, \mathrm{e}}$
}

aManagement Environmental Health Medicine School of ABC, FMABC, Santo Andre, SP, Brazil, bDepartment of Biological Sciences, Federal University of Sao Paulo, UNIFESP, Diadema, SP, Brazil, cFaculty of Medicine, University of Sao Paulo, USP, Sao Paulo, SP, Brazil, dFaculty of Public Health of USP, Department of Maternal and Child Health, Sao Paulo, Brazil, eNational University of La Matanza, UNLaM, San Justo, Buenos Aires, Argentina Email: amaral.jat@usp.br

Received: 14 Jun 2018 Revised and Accepted: 15 Feb 2019

\begin{abstract}
Objective: To investigate the degree of knowledge of the patients enrolled in the Unified Health System of the Medicine School of ABC (Faculdade de Medicina do $A B C$ ) regarding the proper use and disposal of medicaments.

Methods: Participants were recruited for convenience, during their medical appointments at the clinic of the Medical School of ABC (Santo André, Sao Paulo, Brazil) in the period from 04 August to 30 September 2014. Data collection was conducted through a self-administered poll designed specifically for the purpose of this study, which consisted of 25 questions multiple choice about socioeconomic issues and the subject disposal of drugs, consumption and environmental pollution.

Results: We selected the 140 patients' polls. Most of them is of white ethnicity (58\%) and female (58\%). Level of education: $31 \%$ have completed secondary education (31\%) or incomplete graduation (19\%). Most of the participants (76\%) buy drugs without a prescription, and most families (76\%) seek understanding by reading the labels. $71.43 \%$ reported knowing that incorrect disposal of drugs could contaminate the environment, but $78 \%$ reported never having seen or received information about these. After using, $22.15 \%$ maintains the medication at home for future use, $55 \%$ of subjects reported improper disposal sites and $13 \%$ are delivered in health care institutions.
\end{abstract}

Conclusion: Our study has showed that most participants inappropriately use and dispose of drugs, even though they know they can contaminate the environment.

Keywords: Environmental Education, Medicine waste, Public health, Environmental contamination, and drugs

(c) 2019 The Authors. Published by Innovare Academic Sciences Pvt Ltd. This is an open access article under the CC BY license (http://creativecommons.org/licenses/by/4.0/) DOI: http://dx.doi.org/10.22159/ijpps.2019v11i4.27907

\section{INTRODUCTION}

The main source of energy development is the overexploitation of natural resources from the period of the Brazilian Industrial Revolution. On the other hand, in the twentieth century, it was necessary to question as to the rampant development model considering that natural resources are not inexhaustible, and indeed promoted the expansion of solid waste in the country and other types of waste $[1,2]$.

Inadequate management of solid wastes like, disposable containers, used tires and other objects which can collect rain or wastewater provides a suitable place for larvae growth [3]. Due to their impact to the environment and the economy, many scientific studies have been carried to find, for example, the ways of transferring this waste into low-cost valuable products [4]. Environmental management also focus on 3 R's-"Reduce, Reuse, Recycle" of solid waste management [3].

In Brazil, the solid waste were separated for effective management by categories through State Solid Waste Policy created by national Law No. 12,300 (March 2006) and regulated by Decree No. 54645 (August 2009). The last update was in 2010 [5], and the category of health care waste can come from various sectors of large and small sizes as hospital care, medical clinics, pharmacies, dental clinics, home assistance, and the like [6].

Urban's waste is found a fraction of solid waste health which are infectious, the characterization is possible due to the presence of biologic materials [1, 7]. In health care waste is included drugs that are present in the urban residue [8], with the development in technology and biotechnology field of health also contributes to the increase of health waste through the creation and improvement of new techniques and materials [7].

The existing concern is the lack of management of healthcare waste, after their release, causing doubt in the population as to proper disposal and understanding of the risks [1, 9-13]. In order to minimize damage to the environment has been created to No. 283 CONAMA/2005, 2001 updates and complements Resolution No. 05 which provides that evidence and generators establishments must manage their waste to its destination final [6].

In Brazil we can find different compounds and classes of substances in sewage effluent, surface water and sewer [14] treatment plant. Diverse classes of pharmaceutical compounds like analgesic, antidepressant, antihypertensive, contraceptive, antibiotics, steroids and hormones have been detected in water samples from ng/l to $\mu \mathrm{g} / \mathrm{l}$ range; although in small quantity, it can be highly toxic to human, animal, and aquatic lives. [10, 12, 15, 16].

Concern for Environmental Health and think about waste management in Brazil is necessary, from the socioeconomic problematic and the environment [6]. Given the great demand of available drugs and their improper disposal, the man becomes a major focus of the environmental impacts generated by this. To understand this process, it was understood by relevant ascertain the knowledge and awareness of the population about the proper disposal of drugs and their effects on the environment.

This study proposed to investigate the degree of knowledge of the patients enrolled in the Unified Health System of the Medicine School of ABC (Faculdade de Medicina do $A B C$ ) regarding the proper use and disposal of medicaments. 


\section{MATERIALS AND METHODS}

Participants were recruited for convenience, during their medical appointments at the clinic of the Medical School of ABC (Santo André, Sao Paulo, Brazil) in the period from 04 August to 30 September 2014. Inclusion criteria were: being over 18 y of age, accepting to participate and signing the consent form; be literate and receive medical attention at the institution. Exclusion criteria were: not to be over $18 \mathrm{y}$ of age, not to sign the consent form and give up responding to the poll, even if it had already started.

Respondents were well informed that their participation or noncooperation, would not entail any prejudice against the treatment. All participants signed a free and informed consent and the Research Ethics Committee of the Medicine School of ABC approved the project (CEP: 216/2013).

Data collection was conducted through a self-administered poll designed specifically for the purpose of this study, which consisted of 25 questions multiple choice. This poll contained questions about socioeconomic issues and the subject disposal of drugs, consumption and environmental pollution. These specific issues checked if the individual had knowledge about how and where to dispose of medicines, if they knew that this kind of material can cause damage to the environment and people's health, the right way to buy drugs, what types were bought most, and symptoms that they entailed consumption of drugs (Annex 1). For some questions, each respondent could point to more than one alternative (types of medicaments, for example). After answering, the participants handed it over to the investigators.
We used Microsoft® Excel for data tabulation and SPSS (Statistical Package for the Social Sciences, version 20.0) for the descriptive analysis of the data (absolute and relative values).

\section{RESULTS}

We selected the 140 patients' polls. None of the polls has been excluded. In relation to sociodemographic characteristics, most of the respondents is of white ethnicity (58\%), the female was shown to be prominent (58\%) and $46 \%$ of respondents live in the same city of the clinic (Santo André). 78\% of them have their own house, 30\% live with 03 people, and $24 \%$ with 04 people. Majority of respondents (86\%) have access to clean water and $83 \%$ have Internet Network Homecare. Level of education according to the poll pointed out that the preponderance of patients have completed their secondary education $(31 \%)$ or incomplete graduation (19\%).

Respect to economic profile, $49 \%$ have a monthly income of their families in the range of $\mathrm{R} \$ 1,448.00$ to $\mathrm{R} \$ 2,896.00$ (approximately US\$ 630 to US\$1,260, dollar exchange rate at that time). Concerning the profession $54 \%$ work or have worked in the area of trade and banks.

Answers about health status indicated that $10 \%$ had family members with physical or mental illness and in need of therapeutic assistance, the main diagnoses were mental disorders (14\%) and cancer (14\%). Regarding to medicaments, most of the participants (76\%) buy drugs without a prescription, and most families (76\%) seek understanding by reading the labels. Table 1 shows the most common types of medicines available without a prescription. It was noted that, among the symptoms that lead to self-medication, were identified drugs for headache (22\% of cases), colds and influenza (19\%) and fever (18\%).

Table 1: Drugs purchased without a prescription: number and percentile of users (sample =140)

\begin{tabular}{|c|c|c|}
\hline Drugs bought without a prescription & $\mathbf{N}^{\circ}$ users & \% sample \\
\hline Analgesics/antipyretics & 118 & 84.28 \\
\hline Anti-inflammatory & 84 & 60 \\
\hline Cough syrups & 91 & 65 \\
\hline Antibiotics & 32 & 22.86 \\
\hline Nasal decongestants & 72 & 51.43 \\
\hline Allergy/antihistamines & 44 & 31.43 \\
\hline Eardrops (ear) & 10 & 7.14 \\
\hline Remedies for cold/flu & 84 & 60 \\
\hline Ointments & 82 & 58.57 \\
\hline Cream & 48 & 34.28 \\
\hline Eyedrops & 38 & 27.14 \\
\hline Systemic corticosteroids (oral) & 8 & 5.71 \\
\hline Nasal corticosteroids (spray) & 8 & 5.71 \\
\hline Others & 0 & 0 \\
\hline
\end{tabular}

Concerning the validity of the medicaments, it was observed that $37.1 \%$ of users perform this check only at the time of purchase, $25.2 \%$ when they need to use (due to the habit of keeping drugs at home), and $31.1 \%$ reported checking the validity in the two above mentioned moments.

In relation to their knowledge about environmental contamination and correct disposal of drugs, the percentage of individuals who have the understanding that it is controlled landfill reached $44 \%$,
$71.43 \%$ reported knowing that incorrect disposal of drugs could contaminate the environment, but $78 \%$ reported never having seen or received information about these. Of the respondents, $80 \%$ said it has the habit of reading the labels of drugs, but of these $67 \%$ have never read the disposal procedures or unaware that there are such procedures in the leaflets. After using, $22.15 \%$ maintains the medication at home for future use, $55 \%$ of subjects reported improper disposal sites and $13 \%$ are delivered in health care institutions (table 2).

Table 2: Participants knowledge and disposal of drugs (sample $=140$ )

\begin{tabular}{lll}
\hline Knowledge about environmental contamination by the disposal of drugs & \% Sample \\
\hline YES & $\mathbf{N}^{\circ}$ Users & 71.43 \\
NO & 100 & 26.43 \\
No Reply & 37 & 2.14 \\
Local disposal & 3 & 45.72 \\
Kitchen or bathroom trash & 64 & 7.85 \\
Toilet bowl & 11 & 2.15 \\
Drains sinks or tanks & 3 & 12.85 \\
Health institution & 18 & 22.15 \\
Future use & 31 & 9.28 \\
Inadequate response & 13 & \\
\hline
\end{tabular}




\section{DISCUSSION}

This study has investigated the degree of knowledge of the patients regarding the proper use and disposal of medicaments. Our results have showed that most participants inappropriately use and dispose of drugs, even though they know they can contaminate the environment.

It was observed that $50 \%$ of respondents have completed high school or incomplete graduation; however, the understanding even of these is less than expected, since the answer on the right of health materials disposal was divided and only $12.85 \%$ reported doing disposal in health institutions. Evidencing need for information and knowledge to the public [17].

In a study in Japan [18] the importance of education related to this issue focusing on waste disposal has been verified. They assessed 658 nurses attached to an annex office and 585 independent offices on education for patients of use, storage and disposal of drugs [19]. It was found that more than $70 \%$ should be taught how to use and storage of medicines, however, only on the disposal of $47.3 \%$ related to attachment and $53.2 \%$ independent offices educated their patients about how it should be done disposal such waste.

In our results, kitchen or bathroom trash, toilet bowl and drains sinks or tanks were the most cited forms of disposal. According to the situation in which we live, with pollution and its consequences, drugs offer a great danger when is incorrectly discarded $[20,21]$. Waste generated cause environmental imbalance and contribute to the pollution process [22, 23], as well as the generation and spread of various sanitary diseases [6] causing a problem affecting public health.

Previous studies have described the presence of drugs in the nature [24]. A study in a national dam found concentrations of drug compounds such as diclofenac (analgesic/anti-inflammatory), ibuprofen (anti-inflammatory/analgesic/antipyretic) and caffeine (antipyretic/analgesic/stimulant) in the water. It should be noted that even after the treatment of effluents, these compounds might be constantly present in the water used for population consumption [25].

Some strategies have been proposed to improve the management and medicines' disposal situation: drug collection programs, as there are in United States, Canada, Italy and France [26]; greater control over the distribution of drugs [2] and of free samples, over advertisements and inadequate management of pharmacies and other health facilities.

In Brasil, there are public policies on disposal and recommendations, with specific programs for each state, besides the national Law no. $12,305 / 2010$, which instituted the National Policy on Solid Waste. However, the disclosure does not reach the great mass of the population, the spread of information is not effective and awareness to this problem is still small [27], as our results showed.

Brazilian Association of Public Cleaning Companies and Special Waste (ABRELPE) in 2005 accounted for 1,000 tons of waste from health services a day, and only $29 \%$ receive adequate treatment. However, the data are not presented and have not estimated the pharmaceutical material deposited in domestic waste [28, 29].

Even with the negative impacts of drug use and its disposal, we must remember that drugs are essential to human health [30]. The occurrence of drugs wasted and discarded improperly is great [31]. Hospital waste management [32] and pharmaceutical [20] is a major public health problem, involving the economic and social spheres of the population, therefore the discussion of this theme is so important since the wrong disposal of medicines can contaminate the environment $[33,34]$.

We should mention that, even internally, there could be differences in the way of dispensing the medical waste within the country, given its large size and socioeconomic heterogeneity. Our pool only considered specific aspects of the regions where it was conducted. Moreover, we do not check associations between income and knowledge, nor between education level and knowledge of participants. Both points could be considered limitations of the present study. However, we believe that our results can be extended and compared to similar realities in other developing countries.
Literature available about medicine waste presents information regarding the disposal of hospital supplies and the dangers of infectious material; however few articles are current and they talk about domiciliary disposal [24, 25,35]. Excessive accumulation of drugs in homes and errant disposal cannot happen [36]. Future studies are needed in order to describe and disseminate the experience of different countries (with different social and environmental realities), to be established worldwide awareness strategies and proper disposal of these types of waste.

\section{CONCLUSION}

In conclusion, our study has showed that most participants inappropriately use and dispose of drugs, even though they know they can contaminate the environment.

\section{AUTHORS CONTRIBUTIONS}

TMGB, FLAF, EMR, IFA, RDR and TDC analyzed the data and wrote the manuscript. MMR, OR, LAA, VJ and TDC contributed to the study design, data collection and critical review of draft manuscripts. TMGB, JATA and RS assisted with statistical analysis and interpretation of data. All the authors read and approved the final manuscript.

\section{CONFLICTS OF INTERESTS}

All authors have none to declare

\section{ANNEX 1}

Poll: Medicines waste policies and the population knowledge in Brazil

1) Sex:

a. Male

b. Female

2) What is your ethnicity?

a. White

b. Brown

c. Black

d. Yellow

e. Indigenous

3) Which city in region do you live?

a. Santo André

b. São Bernardo do Campo

c. São Caetano do Sul

d. Diadema

e. Other:

4) Your family's residence is:

a. Own residence

b. Rent residence

c. Ceded house

d. Other situation (unregulated subdivision, occupation, etc.)

5) How many people live in your home?

a. 1

b. 2

c. 3

d. 4

e. More than 5

6) Do you have potable water access?

a. Yes

b. No

7) Do you have internet at your house?

a. Yes

b. No

8) What is the monthly income of your family? (Brazilian currency$\mathrm{R} \$)$.

a. None

b. Until R $\$ 724,00$

c. $\mathrm{R} \$ 1.448,00$ to $\mathrm{R} \$ 2.896,00$

d. $\mathrm{R} \$ 2.896,01$ to $\mathrm{R} \$ 4.344,00$

e. $\mathrm{R} \$ 4.344,01$ to $\mathrm{R} \$ 5.792,00$

f. Above R $\$ 7.240,00$

9) What is your level of education?

a. () None/illiterate

b. () Incomplete primary education 
c. () Complete primary education

d. () Incomplete secondary education

e. () Complete secondary education

f. () Incomplete graduation

g. () Complete graduation

10) What is your main job activity?

a. In agriculture, in the countryside, on the farm or in fishing,

b. In industry

c. In commerce, bank or others services.

d. Federal, state, municipal or military government official.

11) Does anyone in your family need medical follow-up due to mental or physical illness? (Proven by medical certificate).

a. No

b. Yes: Who?

Wich one?

12) Do you know the trajectory of trash from your home to the warehouse?

a. I just know it is taken by the garbage truck

b. Sanitary landfill

c. Controlled landfill

d. Open dump

13) Do you know what a landfill is?

a. Yes

b. No

14) Have you ever used or bought over-the-counter medications?

a. Yes

b. No

15) Do your family respects the instructions in the package leaflet?

a. Yes

16) What medications have you bought and/or taken without the advice of a doctor? Check one or more options.

a. () Analgesics/antipyretics for fever

b. () Anti-inflamatories

c. () Cough syrups

d. () Antibiotics

e. () Nasal decongestants

f. () Anti-allergy/antihistamines

g. () Otological drops (for ears)

h. () Cold/flu remedies

i. () Ointments

j. () Cream

k. () Eyes drop

l. () Systemic corticosteroids (oral)

m. () Nasal corticosteroids (nasal spray with corticosteroids)

n. () Others. Wich?

17) Which of the following diseases do you often take medicine for?

a. () Headache

b. () Fever

c. () Cold/Flu

d. () Infections/throat inflammations

e. () Infection/ears inflammations

f. O Sinusitis

g. () Rhinitis

h. O Allergies

i. () Oral lesions

j. () Skin lesions

k. () Other diseases of the head and/or neck

l. () Pulmonary disease

m. () Others:

18) How often do you check the validity of the remedies?

a. () At the time of purchase

b. () When you need to use the medicine

c. () In the two previous situations

d. () Never checks the validity

e. () After months acquired

19) In your opinion, is correct the way you throw away the remedies?

a. Yes

b. No

20) Did you know that the wrong way to dispense medicines could contaminate the environment?

a. Yes

b. No
21) Have you ever seen a campaign that taught the correct way to dispense medicines?

a. Yes

b. No

22) When, in your home, someone uses medication with glass ampoules, syringes and needles, how do you throw this material in the trash? You...

a. Throw away in toilet

b. Throw away in the sinks or tanks

c. Throw away in the kitchen or bathroom trash

d. Give it to a health institution.

23) Do you have the habit of reading the package leaflet?

a. Yes

b. No

If the answer is YES, have you read the package leaflet regarding the correct way to dispense medicines?

a. Yes

b. No

24) Do you respect the instructions in the package leaflet?

a. Yes

b. No

25) How do you dispose of medicines you have already used, such as: tablets, syrups, syringes, and others? You...

a. Throw away in the kitchen or bathroom trash

b. Throw away toilet

c. Throw away in drains of sinks or tanks

d. Give it to a health institution

e. Keep it in case someone gets sick and needs to use it on another occasion.

\section{REFERENCES}

1. Cussiol NAM, Rocha GHT, Lange LC. Quantificacao dos resíduos potencialmente infectantes presentes nos resíduos sólidos urbanos da regional sul de Belo Horizonte, Minas Gerais, Brasil. Cad Saude Publ 2006;22:1183-91.

2. Naime R, Sartor IS, Garcia AC. Uma abordagem sobre a gestão de resíduos de servicos de saude. Rev Espac Saude 2004:5:17-27.

3. Kumar K, Singh PK, Tomar J, Baijal S. Dengue: epidemiology, prevention and pressing need for vaccine development Asian Pacific. J Trop Med 2010;3:997-1000.

4. Alhumaimess M. Gold nanoparticles supported on carbon derived from solid olive waste for epoxidation of cyclootene. Asian J Chem 2018;30:1731-5.

5. Ushizima MM, Marins FAZ, Junior JM. Politica nacional de residuos: cenario da legislacao Brasileira com foco nos residuos eletroeletronicos. SEGet; 2014. p. 16-21.

6. Garcia LP, Ramos BGZ. Gerenciamento dos residuos de serviços de saude: uma questao de biossegurança. Cad Saude Publ 2004;20:744-54.

7. Nascimento TC, Januzzi WA, Leonel M, Silva VL, Diniz CG. Ocorrencia de bacterias clinicamente relevantes nos residuos de servicos de saude em um aterro sanitário brasileiro e perfil de susceptibilidade a antimicrobianos. Rev Soc Bras Med Trop 2009;42:415-9.

8. Silva CB, Liporone F. Deposicao irregular de resíduos solidos domesticos em Uberlandia: algumas consideracoes. Rev Eletronica Geografia 2011;2:22-35.

9. Alves SB, Souza ACS, Tipple AFV, Rezende KCD, Rezende FR, Rodrigues EG. Manejo de resíduos gerados na assistência domiciliar pela estrategia de saude da familia. Rev Bras Enferm 2012;65:128-34

10. Maia M, Giordano F. Estudo da situacao atual de conscientizacao da populacao de santos a respeito do descarte. Rev Ceciliana 2012;4:24-8.

11. Ueda J, Tavernaro R, Marostega V, Pavan W. Impacto ambiental do descarte de farmacos e estudo da conscientizacao da populacao a respeito do problema. Rev Cienc do Amb 2009;5:1-6.

12. Barcelos MN, Peres AP, Pereira IO, Chavasco LS, Freitas DF. Aplicacao do metodo fmea na identificacao de impactos ambientais causados pelo descarte domestico de medicamentos. Eng Amb 2011;8:62-8.

13. Padro MA, Melo DS, Machado KM, Santos SLV, Gir E, Canini SEMS, et al. Residuos potencialmente infectantes em serviços 
de hemoterapia e as interfaces com as doenças infecciosas. Rev Bras Enferm 2014;57:706-11.

14. Bila DM, Dezotti M. Farmacos no meio ambiente. Quim Nova 2003;26:523-30.

15. Nurolaini K, Wong WS, Li Ling C. The extent of medicine wastages in a tertiary hospital in brunei: $10 \mathrm{y}$ ' retrospective study from 2006 to 2016. Asian J Pharm Clin Res 2018;11. Doi https://doi.org/10.22159/ajpcr.2018.v11i7.24789.

16. Carvalho EV, Ferreira E, Mucini L, Santos C. Aspectos legais e toxicologicos do descarte de medicamentos. Rev Bras Tox 2009;22:1-8.

17. Schenkel EP, Fernandes LC, Mengue S. Como sao armazenados os medicamentos nos domicilios? Acta Farm Bonaerense 2005;24:266-70.

18. Ikeda Y. Importance of patient education on home medical care waste disposal in Japan. Waste Management 2014;34:1330-4.

19. Vaz KV, Freitas MM, Cirqueira JZ. Investigacao sobre a forma de descarte de medicamentos vencidos. Cenarium Pharmaceutico 2011;4:3-27.

20. Homedes N, Ugalde A, Chaumont C. Scientific evaluations of interventions to improve the adequate use of pharmaceuticals in Third World countries. Public Health Rev 2001;29:207-30.

21. Assuncao JV, Pesquero CR. Dioxinas e furanos: origens e riscos. Rev Saude Publ 1999;33:523-30.

22. Kummerer K. The presence of pharmaceuticals in the environment due to human use-present knowledge and future challenges. J Environ Manage 2009;90:2354-66.

23. Almeida GA, Weber RR. Farmacos na represa billings. Rev Saude Amb 2005;6:13-7.

24. Fernandes LC, Petrovick PR. Os medicamentos na farmacia caseira. In: Schenkel EP. Cuidados com os medicamentos. 4. ed. Porto Alegre (RS): Editora da UFRGS; 2004.

25. Falqueto E, Kligerman DC, Assumpcao RF. Como realizar o correto descarte de resíduos de medicamentos?. Cienc Saude Coletiva 2010;15:3283-93.
26. Eickhoff P, Heineck I, Seixas LJ. Management and medicines' disposal: a discussion about the problem. Rev Bras Farm 2009;90:64-8.

27. Miranda AC. Desenvolvimento de um metodo para monitoramento da contaminacao do solo pelo farmaco azitromicina: uma abordagem sustentavel. São Paulo Dissertacao [Mestrado em engenharia de produção]Universidade Nove de Julho; 2013.

28. (Secretaria do estado de São Paulo [Associação de combate aos poluentes]. Divisão Técnica de Ações Sobre Meio Ambiente. Available from: http://www.acpo.org.br/medicamentos/ norma.pdf).

29. Kummerer K. The presence of pharmaceuticals in the environment due to human use-present knowledge and future challenges. J Environ Manage 2009;90:2354-66.

30. Pereira Primo L, Rodrigues JPV, Ferreira IML, Dewulf NLS, Abramovicius AC. Gerenciamento de medicamentos em desuso devolvidos por pacientes ambulatoriais de um hospital universitario. Rev Cienc Farm Basica Appl 2014;35:263-9.

31. Tessaro PR, Zancanaro V. Recolhimento e descarte dos medicamentos das farmacias caseiras no municipio de cacador-SC. Rev Interdisciplinar 2013;2:118-28.

32. Massrouje HTN. Medical waste and health workers in Gaza governorates Eastern Mediterranean. Health J 2001;7:1017-24.

33. Tong AY, Peake BM, Braund R. Disposal practices for unused medications around the world. Environ Int 2011;37:292-8.

34. Suzuki S, Hoa PTP. Distribution of quinolones, sulfonamides, tetracyclines in an aquatic environment and antibiotic resistance in Indochina. Front Microbiol 2012;3:1-8.

35. Alvarenga LSV, Nicoletti MA. Descarte domestico de medicamentos e algumas consideracoes sobre o impacto ambiental decorrente. Rev Saude 2010;4:30-4.

36. Pereira Primo L, Rodrigues JPV, Ferreira IML, Dewulf NLS, Abramovicius AC. Gerenciamento de medicamentos em desuso devolvidos por pacientes ambulatoriais de um hospital universitario. Rev Cienc Farm Basica Appl 2014;35:263-9. 